\title{
Article 7: A Commentary on a Much Talked-About 'Dead' Provision
}

\author{
Dimitry Kochenov
}

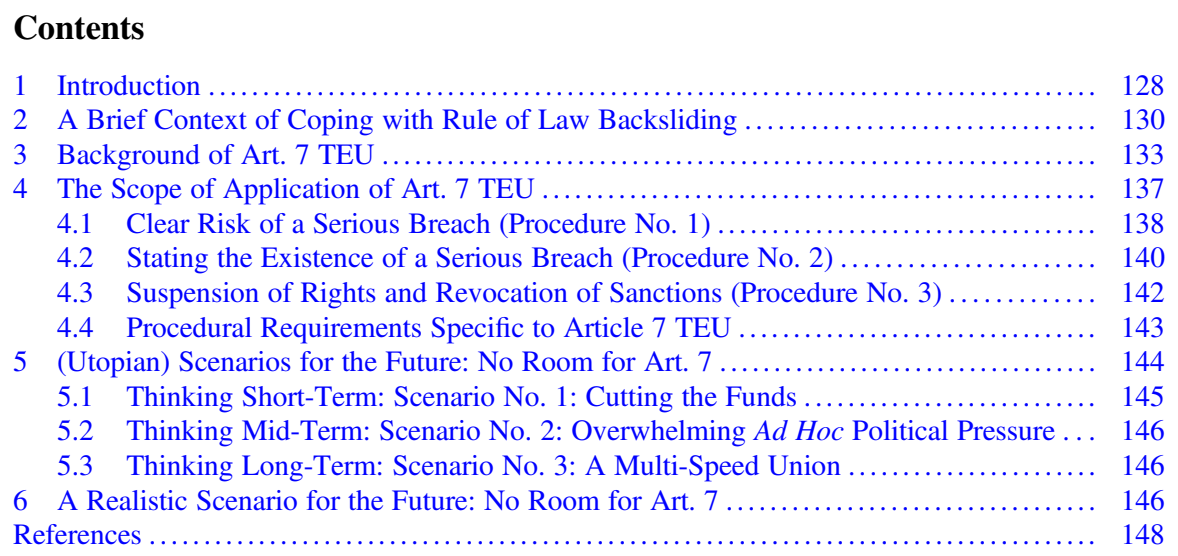

\begin{abstract}
The goal of this chapter is to contribute to the growing Article 7 TEU literature by showcasing the strong and weak points of this provision in the context of the on-going rule of law backsliding in Hungary and Poland threatening the very fabric of EU constitutionalism. This is done by presenting the general context of the institutional reactions to the so-called 'reforms' in Poland and Hungary aimed to hijack the state machinery by the political parties in charge; introducing the background of Article 7 TEU and the hopes of the drafters the provision was endowed with; to move on to the analysis of its scope and all the procedures made available through this instrument as well as the key procedural rules in place. The conclusion restates the necessity of putting our hopes in alternative instruments of combatting
\end{abstract}

This Chapter has been previously published in Polish Yearbook of Inernational Law XXXVIII (2018), 165.

D. Kochenov $(\bowtie)$

University of Groningen, Groningen, The Netherlands

e-mail: D.Kochenov@rug.nl 
rule of law backsliding, outlining three possible scenarios of this, which are not (necessarily) connected to Article 7 as such.

'Article 7 is dead. The European Commission lost.'

Polish Minister of Foreign Affairs on the National TV in December 2018. ${ }^{1}$

\section{Introduction}

What is the situation with the rule of law in the European Union (EU) today? Is the Minister responsible for undermining Polish constitutionalism right? Looking at the most dramatic examples, Poland ${ }^{2}$ has now joined Hungary, ${ }^{3}$ and following the apt description of what is going on provided by Pech and Scheppele, it is possible to characterise the on-going troubles in the EU as 'rule of law backsliding', which is deemed to be a 'process through which elected public authorities deliberately implement governmental blueprints which aim to systematically weaken, annihilate or capture internal checks on power with the view of dismantling the liberal democratic state and entrenching the long-term rule of the dominant party. ${ }^{, 4}$ Considering that more states could follow this approach, the EU's position is, apparently, very weak: new soft law of questionable quality has been produced by each of its institutions. $^{5}$

\footnotetext{
${ }^{1}$ PolsatNews (2018).

${ }^{2}$ European Commission, Reasoned Proposal in Accordance with Article 7(1) of the Treaty on European Union Regarding the Rule of Law in Poland - Proposal for a Council Decision on the Determination of a Clear Risk of a Serious Breach by the Republic of Poland of the Rule of Law [2017] (COM(2017) 835 final). Cf., most importantly: Sadurski (2018), Bodnar (2018), Koncewicz (2018), Pech and Platon (2017), Koncewicz (2016). See also The Venice Commission for Democracy through Law, Opinion on amendments to the Act of 25 June 2015 on the Constitutional Tribunal of Poland, CDL-AD(2016)001, (Venice, 11 March 2016), http://www.venice.coe.int/ webforms/documents/?pdf=CDL-AD\%282016\%29001-e.

${ }^{3}$ European Parliament, Resolution of 12 September 2018 on a proposal calling on the Council to determine, pursuant to Article 7(1) of the Treaty on European Union, the existence of a clear risk of a serious breach by Hungary of the values on which the Union is founded (2017/2131(INL)). Cf., most importantly, Szente (2017), Varju and Papp (2016), Scheppele (2015), Sólyom (2015), Collot (2013), Bánkuti et al. (2012).

${ }^{4}$ Pech and Scheppele (2017), p. 8; Bugarič (2019). Aspects of this phenomenon have equally been branded as 'systemic deficiencies' and 'statutory anti-constitutionalism': von Bogdandy (2019), Bernatt and Ziółkowski (2019). For an overarching analysis, see, Bignami (2019).

${ }^{5}$ Council of the EU Press Release no. 16936/14, 3362nd Council meeting, General Affairs, (2014), pp. 20-21; European Commission, A New EU Framework to Strengthen the Rule of Law (2014) (COM(2014)158); European Parliament, Report with Recommendations to the Commission on the Establishment of an EU Mechanism on Democracy, the Rule of Law and Fundamental Rights (2016) (2015/2254(INL)). For a comparison of all these instruments, see Kochenov et al. (2016), Kochenov and Pech (2016), Oliver and Stefanelli (2016); but see Hirsch Ballin (2016), Kochenov et al. (2015), Kochenov and Pech (2015a); See also Kochenov (2019c).
} 
The Treaties contain a special provision to deal specifically with situations of rule of law backsliding: Art. 7 of the Treaty on European Union (TEU), which however has not emerged as a particularly effective instrument to solve the outstanding problems the Union is facing. Thus the picture is grim, notwithstanding even the belated activation of the Art. 7(1) TEU mechanism against both countries in question. ${ }^{6}$ This activation per se is obviously somewhat misplaced, as we will see, since Art. 7(1) TEU is about 'threats' to values, and the assault on the values in Poland and Hungary are way beyond the 'threat' point, thus begging the question of how appropriate the legal basis chosen actually is. ${ }^{7}$ Indeed, the situation would seem to be evolving extremely fast and mainly_almost uniquely_in the direction of the deterioration of the rule of law and abuses by the executive of independent national institutions. The EU's ability to effectively intervene and bring about significant change, although discussed quite extensively in the literature, has failed to materialise on the ground. ${ }^{8}$ Most worryingly, it seems that there is total disagreement among essentially all the actors involved concerning what should be done, and the political will to sort out the current impasse is lacking at the level of the Member States too.

The goal of this contribution is to contribute to the growing Art. 7 TEU literature 9 by showcasing the strong and weak points of this provision in the context of the on-going rule of law backsliding in Hungary and Poland, which is threatening the very fabric of EU constitutionalism. This is done by presenting the general context of the institutional reactions to the so-called 'reforms' in Poland and Hungary aimed at hijacking the state machinery by the political parties in charge; introducing the background of Art. 7 TEU and the hopes of the drafters the provision was endowed with; then moving on to an analysis of its scope and all the procedures made available through this instrument as well as the key procedural rules in place. The conclusion restates the necessity of putting our hopes in alternative instruments for combatting rule of law backsliding, outlining three possible scenarios of this, which are not (necessarily) connected to Art. 7 as such.

\footnotetext{
${ }^{6}$ European Parliament, 2017/2131(INL), supra note 3; European Commission, COM(2017) 835 final, supra note 2. Pech and Scheppele (2017), Blay-Grabarczyk (2019).

${ }^{7}$ Kochenov (2019a).

${ }^{8}$ Safjan (2018), Waelbroek and Oliver (2017), Jakab and Kochenov (2017a), Pech and Scheppele (2017), von Bogdandy and Sonnevend (2015), Closa and Kochenov (2016), Mori (2016), p. 204; Sedelmeier (2014), Müller (2014).

${ }^{9}$ On Article 7 TEU see, most importantly, Besselink (2017), Wilms (2017), Waelbroek and Oliver (2017), pp. 313-319; Bugarič (2016), Hillion (2016), Bieber and Maiani (2014), Sadurski (2010), Schmidt von Sydow (2001).
} 


\section{A Brief Context of Coping with Rule of Law Backsliding}

Art. 7 TEU, whatever sanctions it contains, cannot be a panacea. Blokker has been absolutely correct in constantly reminding us of the need to deal with the deeper roots of soft totalitarianism and populist turns. ${ }^{10}$ At issue is the phenomenon characterised by Scheppele as 'autocratic legalism', which has deep implications for the very fabric of the societies in question, potentially making the return to liberal democracy difficult. ${ }^{11}$ Moreover, the problem of 'democratic decay', 'backsliding' and populism seems to be a global one, ${ }^{12}$ rather than confined to some EU Member States per se. In the EU, just as elsewhere in the world-from Venezuela to Turkey-'sociological legitimacy' ${ }^{13}$ is crucially important and cannot be ignored. The core issue is how to ensure that the EU's own rule of law is meticulously and consistently upheld, while enjoying, crucially, solid legitimacy? The issue of societal internalisation of the core principles of Art. 2 TEU in the face of a populist wave is fundamental here. Framed in this way, the problem clearly emerges as too ambitious for the EU institutions to digest.

The Council is the most guilty of all the institutions in terms of downplaying the importance of the rule of law backsliding and even presenting key moves by other institutions to tackle it as potentially illegal. The Council legal service has been negative-with no solid arguments for its position ${ }^{14}$ —about the Commission's 'preArticle 7 proposal' ${ }^{15}$ It similarly dismissed the attempts to cut the EU funding of the backsliding states. ${ }^{16}$ Topping the list, however, is the position of the Council Legal Service on the proposal to invite MEP Judith Sargentini to present in Council her report that triggered the request from the Parliament to start Art. 7(1) procedure against Hungary: the Council does not want to listen to Miss Sargentini in person. Its position is based on legal advice which has been given 'orally', with the arguments not disclosed, which however does not shield the Council's position from criticism. A more absurd move could only be to support Hungary in front of the Court, where it has argued - not convincingly — that the Parliament managed to violate its own rules of procedure in adopting the Sargentini Report under Art. 7(1) TEU. ${ }^{17}$

The explanation behind the Council's unwillingness to act could be an obvious one: since the Internal Market is an emanation of deep economic interpenetration, aimed at making outright hostilities between the Member States impossible-

\footnotetext{
${ }^{10}$ Blokker $(2016,2018)$.

${ }^{11}$ Scheppele (2018).

${ }^{12}$ Daly (2019) and Anselmi (2018).

${ }^{13}$ Blokker (2019).

${ }^{14}$ Kochenov and Pech (2015b).

${ }^{15}$ Council of the European Union, Opinion of the Legal Service 10296/14, 14 May 2014, especially para. 28.

${ }^{16}$ Kelemen et al. (2018).

${ }^{17}$ CJEU, Case C-650/18 Hungary v. European Parliament (pending at time of writing). Cf. Kochenov (2019b).
} 
precisely the reason behind picking economic tools to achieve the goal of peace ${ }^{18}$ it has shaped the day-to-day reality of European integration, leaving no room for Art. 7 TEU. The very logic of the provision, which is both deeply politicised and deeply confrontational, contradicts the logic of the Internal Market and the rich Member States potentially stand to lose a lot as a result of taking a principled value-laden position on rule of law backsliding. This is why expecting too much of the Council-and, by extension, of Art. 7 TEU-would be naïve. Unless something truly terrible happens in a backsliding Member State, ${ }^{19}$ the Internal Market, after all, functions as designed. ${ }^{20}$

When the Council is naturally ill-inclined and other EU institutions are profoundly ineffective, the CJEU, like in Andersen's tale, de facto plays the role of the last soldier standing. It 'stands' by gradually learning from own mistakes and from the significant missteps of the Commission-especially in the 'age-discrimination' cases, where the hijacking of the Hungarian judiciary went unnoticed ${ }^{21}$ bringing about a radically more robust result in Commission v. Poland on virtually identical facts in the context of an attempted assault on the Supreme Court (more on this in the last section). ${ }^{22}$

Undoubtedly however, the Court cannot solve the outstanding problems alone, even when helped by the national judiciaries. A much more concerted effort is required of all the actors involved in order to get the EU out of the current impasse. In the meantime, the supranational political party groups, instead of helping, seem to aggravate the situation. ${ }^{23}$ This inaction-or even attempts to hinder positive change - on the part of the political institutions helps the powers of the backsliding Member States consolidate their assault upon EU values even further, undermining the truly heroic efforts of the Court of Justice and the national courts in Poland, ${ }^{24}$ Ireland, ${ }^{25}$ and elsewhere in the Union. The 'stone-by-stone' approach of the CJEU, ${ }^{26}$ although unable to solve the outstanding problems by itself, nevertheless gives reason for optimism and could amount to one of the key legacies of the Lenaerts court.

\footnotetext{
${ }^{18}$ This is exactly why the objective of peace has proven to be unexportable: Williams (2009). Cf. Kochenov and Basheska (2016).

${ }^{19}$ But see Hirsch Ballin (2016).

${ }^{20}$ For a number of divergent perspectives, see Amtenbrink et al. (2019).

${ }^{21} \mathrm{CJEU}$, Case C-286/12 Commission v. Hungary (compulsory retirement of judges), ECLI:EU: C:2012:687; cf. Belavusau (2013).

${ }^{22}$ CJEU, Case C-619/18 R Commission v. Poland, ECLI:EU:C:2018:852 and EU:C:2018:1021, Order ex parte of 19 October 2018 and Order of 17 December 2018; cf. Editorial comment (2019). Cf. Kochenov and Bárd (2019).

${ }^{23}$ Kelemen (2017).

${ }^{24}$ Biernat and Kawczyńska (2018).

${ }^{25}$ See the whole saga surrounding CJEU, Case C-216/18 PPU Minister for Justice and Equality (LM), EU:C:2018:586.

${ }^{26}$ As explained by President Lenaerts in the context of the EU citizenship law field: Lenaerts (2015), p. 1.
} 
The inventiveness of the autocrats, populist voting, and the weakness of the EU's track record and current position on values are no doubt among the large variety of factors that have produced a previously unimaginable situation; whereby the EU harbours Member States which, besides obviously not qualifying for Union membership if they were to apply today (even the EU's usual 'window dressing' of rule of law conditionality notwithstanding $)^{27}$ are working hard to undermine key principles the EU was created to safeguard and promote: democracy, the rule of law, and the protection of fundamental rights. ${ }^{28}$ The underlying issue is the creation of a modus vivendi where the EU's own instrumentalist understanding of the rule of law, including principles such as mutual trust or the autonomy of EU law, reinforces rather than jeopardises the respect for values enshrined in Art. 2 TEU. ${ }^{29}$

The claims that little to nothing can be done under the current legal frameworkwhich are heard with remarkable regularity - are entirely baseless, as Hillion, Besselink and other scholars have consistently pointed out. ${ }^{30}$ In making such claims the Commission and other institutions point to the fact that the powerlessness is not caused by an absolute lack of Treaty instruments that would warrant intervention. Rather, the instruments that are available are, apparently, too strong, or to put it differently, too toxic to be used. The EU has a 'nuclear' option, we are told: Art. 7 TEU, which should not be used too easily. Indeed, the institutions observed the deterioration of the Rule of Law in Hungary and Poland while embroiled in a clearly useless commotion of constantly inventing new rules instead of using the tools at hand. Art. 7 TEU was only activated at the end of 2018, offering too little too late. ${ }^{31}$

The talk of the legal difficulties surrounding the provision seems to be triggered by two considerations. Firstly, the Member States and the institutions alike apparently lack a strong and unreserved political commitment to throw their full weight behind the defence of the Rule of Law. Secondly-and most importantly-Art. 7 TEU does not per se guarantee any successes in the fight. Its effectiveness is highly doubtful. Such doubts stem from two considerations. The first, as already mentioned, is the very logic of the internal market-created to socialise and intertwine the Member States' economies to ensure a lasting peace and common prosperity, the internal market logic is poorly equipped to deal with the backsliding states due to the overwhelming economic costs any serious intervention is prone to generate. These costs will be, to a large extent, external to the backsliding Member State. For example, in order to initiate regime change in Poland one needs to come up with really stinging measures, which however will unquestionably hamper the success of German, Dutch and British businesses in Warsaw, Cracow and other places. The second consideration relates to the EU's very nature: as it stands it is not necessarily

\footnotetext{
${ }^{27}$ De Ridder and Kochenov (2011).

${ }^{28}$ As well as other values expressed in Art. 2 TEU; Rideau (2012), Pech (2010), Kochenov (2017a). Cf. Carpano (2005).

${ }^{29}$ Klamert and Kochenov (2019).

${ }^{30}$ Hillion (2016), Besselink (2017) and Scheppele (2016).

${ }^{31}$ Kochenov et al. (2017).
} 
well positioned to lecture the Member States on democracy and the Rule of Law-an argument we have to take into account notwithstanding how urgent and pressing we think the need for action might be. ${ }^{32}$ These two elements explaining why Art. 7 TEU was only activated so late are unquestionably related. If one is asked to trigger a legal mechanism which does offer any guarantees of success of the intervention-knowing that the activation will harm businesses across Europe and is bound to bring about new scrutiny of the EU's own track-record-the doubts appear not so irrational anymore.

\section{Background of Art. 7 TEU}

The initial versions of the Treaties relied on the presumption of compliance by the Member States with the - then non-codified-values of the Communities, expressed in the Schuman Declaration ${ }^{33}$ and the unwritten founding values of the Union, ${ }^{34}$ which gradually crystallised in the context of its enlargements. ${ }^{35}$ The enforcement of compliance was strictly confined to the scope of the acquis, via what are now Arts. 258 and 259 of the Treaty on the functioning of the European Union (TFEU) (later reinforced by Art. 260 TFEU). ${ }^{36}$ This initial design created an unbalanced picture, where compliance with the rules of EU law was strictly enforced while the enforcement of the core principles on which all the law in question rested remained seemingly out of reach for the supranational institutions in a situation where, ironically, the legal nature of the core principles of EU law in terms of their enforceability and contents remained and remains largely unclear. ${ }^{37}$ What this configuration made obvious, however, was that the acquis did not necessarily include the key values. So Poland, the crucial example of the aberration of constitutionalism in Europe, is also the only 'Developed Market' ${ }^{38}$ in Central and Eastern Europe, while Hungary, the second key example of aberration of constitutionalism, is the only 'Partly Free" ${ }^{39}$ regime in the history of the EU. Thus, respecting the acquis and Art. 2 TEU values do not seem to correlate. As a consequence, once one turns to the issue of enforcement, the enforcement of the acquis and the enforcement of values cannot be regarded as one and the same thing. ${ }^{40}$

\footnotetext{
${ }^{32}$ Weiler (2016) and Kochenov (2015).

${ }^{33}$ Weiler (2012).

${ }^{34}$ Perju (2018).

${ }^{35}$ Kochenov (2005).

${ }^{36}$ Gormley (2017), Wennerås (2017). Bárd and Śledzińska-Simon (2019).

${ }^{37}$ Kochenov (2017b).

${ }^{38}$ Day (2018).

${ }^{39}$ Simon (2019).

${ }^{40}$ Kochenov (2017a).
} 
Given the importance of the duties of loyalty and mutual trust, which lie at the foundation of EU law, the articulation of supranational policing of compliance with the values was only a matter of time. ${ }^{41}$ This was particularly so because the diversity of the Member States has been increasing with the numerous successive rounds of enlargement, incorporating a large number of newly-democratised and posttotalitarian states seeking democracy, the rule of law, and political stability in the Union. ${ }^{42}$ From the incorporation of Greece, Spain and Portugal on to the former republics and satellite states of the USSR, the issue of enforcing the values of the EU in cases of eventual breaches was becoming more and more acute: the tradition of a democratic rule of law-based state in these new Member States, so engrained as the basis of EU law, was largely lacking. Art. 7 TEU now attempts to bridge the gap between the presumptions of the founding fathers that all the Member States are good enough to achieve the baseline values and the need to enforce the values of the Union should this presumption turn out to be untenable. The scope of this provision, which is, like Arts. 2 and 49 TEU, necessarily broader than what has been conferred on the EU under Art. 5(1) TEU, is key to the understanding of the instruments Art. 7 contains, as will be discussed below under 'scope'.

The acuteness of the potential problems arising from the discrepancy between the crucial importance of the presumption of compliance of the Member States with the values of the Union and the Union's inability to check whether this indeed is the case-let alone intervene-was quite apparent from early on. Already in 1978 the Commission contemplated a proposal for a sanctions mechanism against the backdrop of Greek accession and the obvious threat of backsliding from democracy and the rule of law in that economically weak, newly-democratised state, fresh from the experience of the colonels' junta rule. ${ }^{43}$ It is thus not surprising that the draft EU Treaty prepared by the European Parliament (EP) in 1984 contained such a mechanism. ${ }^{44}$

Since 1991, the EU has included 'human rights clauses' in all association and cooperation ('Europe-') agreements and incorporated these into the fabric of the pre-accession political conditionality in the areas of democracy, the rule of law, and human rights-which are now at the core of Art. 2 TEU. ${ }^{45}$ Deployed in the pre-accession context via the Copenhagen Criteria, ${ }^{46}$ the sanctions for non-compliance with the values and the core principles of the Union had only limited implications for the Member States once full membership had been secured, creating the so-called 'Copenhagen dilemma'. Beyond the so-called Cooperation

\footnotetext{
${ }^{41}$ Closa (2016).

${ }^{42}$ Sadurski (2012).

${ }^{43}$ Tsoukalis (1981).

${ }^{44}$ Article 44, Draft Treaty Establishing the European Union (1984) (never entered into force). The Court of Justice was supposed to play the key role in finding a breach. Cf. Mastroianni (2017a), pp. 611-612.

${ }^{45}$ Kochenov (2007) and Inglis (2000).

${ }^{46}$ Hillion (2004) and Janse (2019).
} 
and Verification Mechanism, which was only applicable post-accession to Bulgaria and Romania, the new Member States were out of reach of values enforcement, if not for Art. 7 TEU. ${ }^{47}$

The current instrument goes back to the Treaty of Amsterdam-i.e. was adopted in direct anticipation of the 'big-bang' Eastern enlargement of the EU-and was explicitly linked to ex Art. 6 TEC, which listed the then 'principles' on which the Union is built, which now regrettably came to be recodified as 'values' in Art. 2 TEU. $^{48}$

From the very beginning Art. 7 TEU followed the principle of equal treatment of the Member States. Although clearly designed with the new Member States in mind, the instrument was framed from its very inception to apply to all the Members, unlike, for instance, the Cooperation and Verification Mechanism.

The initial version of the provision contained only a sanctioning mechanism for a 'serious and persistent breach' of values, which made the provision unusable in the event a swift reaction to a breach was necessary, which was exactly the situation in Austria in 2000 as perceived by the majority of the European capitals following the securing of the participation of the extreme-right FPÖ in government in Austria. The reaction to this electoral result came in a series of illegal ad hoc 'bilateral sanctions' imposed on Austria by the 14 other Member States and orchestrated by the EU institutions, which in addition to not relying on Art. 7 TEU were entirely placed outside of the framework of EU law. ${ }^{49}$ Austria has never been accused by the Commission or any other EU institution of violating any of the EU's values and principles. Moreover, the assessment by the 'three wise men' of the situation on the ground concluded that ad hoc sanctions were introduced for no good reason at all. ${ }^{50}$ It is thus beyond any doubt that Austria was mistreated in breach of EU law. ${ }^{51}$ The 'FPÖ crisis' teaches us, ironically, that the EU does not need any law or a formal legal basis if the political will is in place to act-so much for the supranational rule of law, an issue we return to infra. The current Hungarian and Polish situations cannot be compared to the former Austrian one, since the Hungarian and Polish situations are long in the state of 'constitutional capture', which is well documented both by European institutions and in the academic literature.

The Austrian story had two direct and important consequences. Firstly, it led to a chilling effect, preventing the effective deployment of Art. 7 TEU when problems with values are strongly observable on the ground: Austria was constantly and erroneously cited by the EU institutions as a tale of caution about the momentous

\footnotetext{
${ }^{47}$ Vachudova and Spendzharova (2012).

${ }^{48}$ Pech (2010); cf. Levrat (2018), p. 157.

${ }^{49}$ The EU Council Presidency of 31 January 2010 formally launched the sanctions against Austria on behalf of all the other Member States.

${ }^{50}$ Ahtisaari et al. (2001).

${ }^{51}$ Lachmayer (2017), Besselink (2017), von Toggenburg (2001), Merlingen et al. (2001), Bribosia et al. (2000).
} 
implications of the use of Art. 7, even though the provision had not been used then. ${ }^{52}$ Secondly, it led to the upgrade of Art. 7 by the Treaty of Nice. The preventive mechanism in Art. 7(1) to deal with serious and persistent threats of a breach of values goes back to the Treaty of Nice. Art. 7(5) was changed with the Treaty of Lisbon.

As the provision stands today, it thus incorporates three different procedures which can be deployed to safeguard the values of Art. 2 TEU:

(1) a procedure to declare the existence of a 'clear risk of a serious breach' of the values referred to in Art. 2 TEU and the adoption of recommendations how to remedy the situation addressed to the Member State in breach (Art. 7(1) TEU);

(2) a procedure to state the existence of a serious and persistent breach of values (Art. 7(2) TEU);

(3) and a sanctioning mechanism following a finding of a serious and persistent breach (Art. 7(3) TEU).

The above procedures should not be regarded as small steps in a grand chronological order of things. In fact, Art. 7 does not exclude the possibility of starting the procedure laid down in Art. 7(2) TEU directly, i.e. all the three paragraphs of it are not part of one procedure with three steps. This fact is constantly forgotten in the political speeches by the key actors responsible for the operation of Art. 7 TEU. ${ }^{53}$ The most popular presentation of Art. 7 TEU today-a consequence of the postAustria chilling effect-is to refer to it as the 'nuclear option' ${ }^{44}$ This is based on the assumption that invoking the provision is extremely difficult and the results of its application are too devastating to make it practicable. ${ }^{55}$ This view clearly ignores the differences between the three procedures of Art. 7 TEU and is not justifiable from the legal point of view. ${ }^{56}$ Moreover, given the overwhelming costs of regime change and our general knowledge-based on countless historical examples - that sanctions are not the most effective way to bring about compliance, the potential effectiveness of Art. 7 TEU is clearly questionable, even if not impossible to attain.

The concerns of the drafters who included Art. 7 TEU into the Treaties have recently been proven entirely justified, as outstanding problems persist in the field of adherence to values. Following the 'reforms' of the Fidesz party in Hungary starting with the second Orbán government, which used its constitutional supermajority to provide an overwhelming overhaul of the totality of the legal-political system in the country with a view to building an 'illiberal democracy' à la Putin, it is clear that the problems Art. 7 was designed to tackle are not at all theoretical. ${ }^{57}$ Adding to the situation in Hungary, where according to the Venice Commission the Constitution

\footnotetext{
${ }^{52}$ E.g. Timmermans (2015).

${ }^{53}$ Besselink (2017) and Wilms (2017).

${ }^{54}$ E.g. Barroso (2012).

${ }^{55}$ For strong arguments against this view, see Besselink (2017).

${ }^{56}$ Kochenov and Pech (2016), Oliver and Stefanelli (2016).

${ }^{57}$ Scheppele (2017), Szente (2017), p. 456; Tóth (2017).
} 
ended up being turned into a political tool of one-party rule, Poland followed suit after the election of Prawo $i$ Sprawedliwość (PiS) in $2015 .^{58}$ Lacking a supermajority to change the Constitution, the Polish government has simply ignored it, systematically failing to comply with its laws: a situation amply documented by scholars and analysed in detail by the Venice Commission. ${ }^{59}$ Democratic- and rule of law-backsliding is thus on the rise in the EU and there is no guarantee that Poland and Hungary will not be joined by more Member States which fail to adhere to the values of Art. 2 TEU.

What Art. 7 has to say about the involvement and jurisdiction of the Court begs the question of whether the provision is largely political in nature. As per Arts. 19 TEU and 269 TFEU, the CJEU only has jurisdiction over procedural issues. ${ }^{60}$ The observance of the voting arrangements applying to the EP, the European Council and the Council, as laid down in Art. 354 TFEU, could thus be policed by the Court. Importantly however there is no express exclusion of Art. 7 from the CJEU's jurisdiction, which means that the Court could be called upon to check how the institutions involved used their discretion in a concrete case, broadening judicial involvement somewhat compared with the silence of the provision itself about the Court. Given the limited involvement of the judicial power, as well as the fact that the Commission does not have an exclusive right of initiative, Art. 7 TEU remains a blend of law and politics. ${ }^{61}$ It is a fundamental fact, however, that both these components unquestionably play an important role in the functioning of this provision.

\section{The Scope of Application of Art. 7 TEU}

The scope of application of Art. 7 TEU is necessarily broader than what is implied by the principle of conferral: it is not confined to the scope of the acquis. As explained by the Commission, Art. 7 'seeks to secure respect for the conditions of Union membership. There would be something paradoxical about confining the Union's possibilities of action to the areas covered by Union law and asking it to ignore serious breaches in areas of national jurisdiction. If a Member State breaches the fundamental values in a manner sufficiently serious to be caught by Article 7, this is likely to undermine the very foundations of the Union and the trust between its members, whatever the field in which the breach occurs. ${ }^{26}$ This position of the

\footnotetext{
${ }^{58} \mathrm{Cf}$. Bugarič (2015).

${ }^{59}$ Sadurski (2018).

${ }^{60}$ Cf. CF, Case T-337/03 Luis Bertelli Gálvez v Commission, ECLI:EU:T:2004:106; Case T-280/09 Morte Navarro v. Parliament, EU:T:2010:28; Besselink (2017), p. 133.

${ }^{61}$ Williams (2006).

${ }^{62}$ European Commission, Article 7 of the Treaty on European Union - Respect for and promotion of the values on which the Union is based (COM(2003) 606 final), 5 .
} 
Commission finds overwhelming support in the literature. Only a very broad view of the scope of Art. 7 TEU can make this provision an effective tool for safeguarding the EU's values.

All in all, as a lex specialis with a remarkably broad scope of application, Article 7 clearly does not preclude the application of Arts. 258, 259 and 260 TFEU in the area of the defence of EU values. While some value violations can clearly fall within or are paralleled by a breach of the acquis, a series of systemic acquis violations could also amount to a serious breach of values. ${ }^{63}$ This is why the Commission insists in its 'Rule of Law Mechanism' on approaching Art. 7 and standard infringement proceedings as deployable side by side. ${ }^{64}$

\subsection{Clear Risk of a Serious Breach (Procedure No. 1)}

Out of the three procedures contained in Art. 7 TEU, initiating 7(1) in order to state a clear risk of a serious breach of values of Art. 2 TEU and address recommendations on how to remedy the situation to the relevant Member State can be done by the broadest array of actors: $1 / 3$ of the Member States, the EP, or the European Commission. Compare this with $1 / 3$ of the Member States and the Commission for the initiation of 7(2), and only the Council for the initiation of the actual sanctioning procedure in Art. 7(3) TEU. All the three procedures are in clear deviation from the main principle that the Commission holds the exclusive right of initiative in EU law.

The aim of opening up the procedure to so many possible initiators clearly seems to have been to make it easier to use, compared with other elements of Art. 7. It is undoubtedly true that both under-enforcement and over-enforcement of Art. 2 TEU values could create problems. ${ }^{65}$ Yet, given that the $7(1)$ procedure cannot possibly lead to sanctions, as for the initiation of 7(3) by the Council the statement of a breach under 7(2) is required, the essence of 7(1) seems to lie in pushing the Member States where the breach could occur to engage in dialogue with the EU institutions in order to prevent a possible breach. This is confirmed by the provision's authorization, addressed to the Council, to issue recommendations to the Member State concerned in order to prevent a breach of values from occurring. The same procedure-a $4 / 5$ majority in the members of the Council with the consent of the EP, is used both for the statement finding the existence of a serious risk of breach and for the adoption of the recommendations to be addressed to the Member State on the brink of breaching the values. Moreover, basic requirements of the rule of law have to be observed throughout, i.e. the Member State subjected to the procedure has to be heard. The

\footnotetext{
${ }^{63}$ Scheppele (2016).

${ }^{64}$ European Commission, supra note 5; European Parliament, supra note 5.

${ }^{65}$ Wilms (2017).
} 
institutions also have to react to the changes on the ground by regularly verifying whether the grounds behind triggering Art. 7(1) TEU still persist.

With the Commission, the EP, and 1/3 of the Member States able to initiate the procedure, it is obvious that the prevailing opinion of Art. 7's 'nuclear' nature is exceedingly exaggerated. Moreover, the 4/5 majority of the members of the Council is not so difficult to reach, given that the Member State subjected to the procedure will necessarily not be allowed to cast a vote. This threshold, however high it seems to be, is clearly far below the unanimity in the European Council required for a statement of an actual breach under Art. 7(2) TEU. It is notable in this regard that Art. 7, which requires the opinion behind the initiation of 7(1) to be 'reasoned', also requires the initiating actors to do their 'homework' and prepare the case by collecting and systematising the necessary information and evidence. Such preparatory work is clearly implied in the text of the provision.

Given that the Art. 7(1) procedure is relatively easy to trigger, the arguments to the contrary underlying the Commission's 'Rule of Law Mechanism'-a non-binding explanation on how the Commission will prepare its own activation of Art. 7(1) or 7(2) TEU ${ }^{66}$ — are hardly convincing. In introducing the mechanism, the Commission aimed at introducing some informal dialogue with the problematic Member State before Art. 7-the misnamed 'nuclear option'-is triggered. The Commission would thus address recommendations to that Member State and receive replies: a procedure criticised by the Council Legal Service; but for very bad reasons, given that as one of the initiators of the 7(1) (and also 7(2)) procedures the Commission clearly has to have internal rules for judging the situation on the ground and the collection of evidence to prepare its Reasoned Opinion. ${ }^{67}$ However, the Rule of Law mechanism as introduced looks suspiciously like a double of Art. 7 (1) TEU-only with no involvement of other institutions. ${ }^{68}$

The only effect of the mechanism's deployment can be a delay in the triggering of Art. 7-even though other institutions having the power to trigger Art. 7 clearly are not obliged to wait for the Commission to finish with the non-Treaty mechanism of its own creation. In practice the delay is the least of the evils created by the Commission in order to ultimately not trigger Art. 7 . When such triggering was needed, it showed three things. ${ }^{69}$ Firstly, it showed that the Commission is incapable of being coherent and consistent in managing its own newly-created procedure. The Mechanism has never been triggered against Hungary, even though the situation there was as bad - if not worse - than in Poland, against which the Mechanism was triggered. Secondly, it demonstrated that the Commission is incapable of sticking to the steps of its own procedure: following Poland's de facto refusal to cooperate and following the Commission's recommendation under the Mechanism, the Commission, instead of triggering Art. 7(1) TEU as its own Mechanism required, came up

\footnotetext{
${ }^{66}$ European Commission, supra note 5; Kochenov and Pech (2015b).

${ }^{67}$ Council of the European Union, supra note 15; Kochenov and Pech (2015b).

${ }^{68}$ Kochenov and Pech (2016).

${ }^{69} \mathrm{Id}$.
} 
with a new, supposedly ad hoc recommendation instead, while the situation with the Rule of Law and democracy in Poland continued to deteriorate at an increasing pace. Thirdly, it demonstrated that triggering Art. 7 and its related mechanisms should be done without committing grave tactical mistakes: having moved against one out of the two current backsliding Member States, the Commission handed the veto power over any serious move under Art. 7(2) TEU against Poland to Hungary, making the deployment of the Treaty provision de facto impossible as a result of its own inventiveness and masking profound indecision. In the event the Rule of Law Mechanism is now regarded as a semi-official step preceding the deployment of Art. 7 TEU-which could be a possibility in practice-the undermining of the effet utile of this provision by the Commission would extend even further, creating an unwelcome and dangerous precedent.

The main question that the Rule of Law Mechanism supposedly had to answer is how to decipher a threat of a serious breach of Art. 2 values. In this sense the mechanism is useful in that it builds on the Venice Commission practice (see the discussion of Art. 2 TEU) in defining the elements of the rule of law, which could be useful to the institutions in finding a risk of breach under Art. 7(1) TEU. Moreover, the Commission relies on the Venice Commission's opinions in its Rule of Law recommendations.

It is fundamental to keep in mind that a statement finding the existence of a serious risk of breach under Art. 7(1) TEU is not necessary to activate Art. 7(2) TEU. The same applies, of course, to the Commission's Rule of Law Mechanism which, as the Commission itself stated, is not obligatory and not legally binding. ${ }^{70}$ Although activated at the time of this writing against both Poland and Hungary, Art. 7(1) TEU is too little too late: both countries are at such a stage of backsliding that only pro-government trolls could benevolently characterise it as a 'threat': the capture of the state is a done deal in both countries - and this is absolutely not what Art. 7 (1) TEU could in any way remedy. By saying that the provision is 'dead', the Polish minister could not be more right, in part: it is both dead and misused.

\subsection{Stating the Existence of a Serious Breach (Procedure No. 2)}

There is a huge difference between a mere 'serious threat' of a breach of values and a serious breach of values actually observable in a Member State of the Union. This difference explains the existence of a separate procedure in Art. 7 TEU for finding such a breach, as well as the definitively higher thresholds required by this procedure: unanimity in the European Council and consent of the EP. Unlike Art. 7(1), Art. 7(2) cannot be initiated by the European Parliament, even though the EP can, under its own Rules of Procedure, call on others to act in the context of both

\footnotetext{
${ }^{70}$ European Commission, supra note 5 .
} 
paragraphs in question. ${ }^{71}$ Even taking into account the fact that unanimity does not imply that each member of the European Council—not counting the representative of the Member State potentially subjected to 7(2), which will not, logically, take part in the vote- has to vote in favour of triggering the procedure, ${ }^{72}$ this makes finding the existence of a serious breach procedurally very difficult.

This difficulty is not illogical, since a simple breach of Art. 2 TEU is not enough to activate Art. 7(2) TEU. What is required-and what is meant by 'serious'-is presumably the systemic nature of the breach, which means that the institutions of the Member State concerned cannot, on their own, successfully resolve the problem of failing to adhere to EU values. ${ }^{73}$ In this context it is only logical to have a procedure in place that makes it extremely difficult to over-police Art. 2 TEU, which is the objective behind the high thresholds contained in Art. 7(2) TEU. The emphasis on 'systemic' helps understand why the question of Art. 7(2) has never been raised with regard to some Member States which have manifestly underperformed under Art. 2-like Berlusconi's Italy with its terrible track-record on media pluralism; ${ }^{74}$ or Sarkozy's France deporting EU citizens of Roma origin in violation of EU law. ${ }^{75}$ If there is a certain 'spectrum of defiance', Art. 7(2) TEU only covers the absolute extremes of such defiance. ${ }^{76}$ What is required is the constitutional capture of the Member State's institutions, resulting in the paralysis of the liberal democracy and rendering making it impossible for the State's institutions to make auto-corrections (as were made in Italy and France). ${ }^{77}$ Hungary and Poland are cases in point, as they represent an example of ideological defiance: a choice made by the government to reform the Member State institutions (in the case of Poland in direct violation of the Constitution and the decisions of the Constitutional Court ${ }^{78}$ ) in such a way as to make wholehearted adherence to the values of Art. 2 TEU impossible.

While naming and shaming could be a potent tool for change, in order to be effective the shaming of those Member States which have chosen a path of systemic non-compliance needs to be backed by possible sanctions, as in and of itself it may have little effect on the ground. This is why, while the main outcome of a successful deployment of Art. 7(2) TEU is a statement finding a serious breach by the Member State concerned of the values of Art. 2 TEU, the core significance of the 7

\footnotetext{
${ }^{71}$ European Parliament, Rule 83, 'Rule of Procedure' (2014) (10296/14).

${ }^{72}$ Art. 7 TEU does not limit its activation to one Member State at a time, so in a situation where more than one Member State is suspected of a breach of Art. 2 values, the activation of Art. 7 against both states is indispensable to avoid the blockage of the Art. 7 procedures by the backsliding Member States supporting each other.

${ }^{73}$ von Bogdandy and Ioannidis (2014).

${ }^{74}$ CJEU, Case C-380/05 Centro Europa 7 S.r.l., ECLI:EU:C:2008:59. Cf. Mastroianni (2017b).

${ }^{75}$ Carrera and Faure Atger (2010).

${ }^{76}$ Jakab and Kochenov (2017b), p. 3.

${ }^{77}$ Müller (2015).

${ }^{78}$ Koncewicz (2018).
} 
(2) procedure seems to lie in the fact that it opens the way to the triggering of the Art. 7(3) procedure by the Council, thus making real sanctions a possibility-unlike in the case of the 7(1) procedure.

\subsection{Suspension of Rights and Revocation of Sanctions (Procedure No. 3)}

The third procedure is contained in Art. 7(3) TEU, which goes beyond the 'shaming' resulting from the deployment of the 7(1) and 7(2) procedures and implies actual sanctioning of a Member State. This procedure is initiated by the Council and requires a reinforced qualified majority voting (QMV), since Art. 354 TFEU makes a reference to the requirements of Art. 238(3)(b) in this respect, implying the support of at least $72 \%$ of participating Council Members comprising $65 \%$ of the Union population (again with the representative of the Member State subjected to the procedure not taking part in the vote or affecting any counts towards the vote as per Art. 354 TFEU). Yet the procedural threshold is very high, since Art. 7(3) TEU cannot be initiated without a successful deployment of Art. 7(2) TFEU.

The 7(3) procedure is suitably vague so as to allow the Council to adapt the exact scope of the sanctions as it sees fit with a view of maximizing the likelihood of compliance in the Member State concerned. While the provision speaks of the suspension of 'certain rights deriving from the application of the Treaty', it is clear that the sanctions meant to be invoked can be either economic and non-economic in nature. Both access to EU funds and the voting of the Member State in breach in the Council - just to give two examples — can be affected. While the academic literature is sceptical about the effect of the sanctions, in those cases when a Member State is heavily reliant on EU funds and concerned about its prestige in EU institutions these could probably bring about the desired effect, although there is no successful example to cite here since Art. 7(3) TEU has never been invoked.

What is absolutely clear, vagueness notwithstanding, is that Art. 7(3) does not authorise the exclusion of the Member State from the Union: the very issue of membership of the Union cannot be put in question. ${ }^{79}$ Only Art. 50 TEU provides guidelines for leaving the Union. ${ }^{80}$

Under Art. 7(4) TEU, lifting the sanctions is very straightforward: again, a simple QMV in the Council without the participation of the violator state is required. Importantly, the same procedure applies to altering the substance of the sanctions in place, giving the Council sufficient flexibility to react to the changes on the ground in the Member State concerned.

\footnotetext{
${ }^{79}$ Besselink (2017), p. 130.

${ }^{80}$ Blagoev (2011).
} 


\subsection{Procedural Requirements Specific to Article 7 TEU}

Now let us look in some more detail at Art. 354 TFEU, which lays down the rules of the procedural aspects of Art. 7 TEU. There are several significant points of difference compared with the familiar procedures used by the institutions involved, which can be found elsewhere in the Treaties. Firstly-and most importantlyalthough Art. 354 TFEU refers to a concrete Member State which is to be excluded from voting in such cases, the wording clearly implies that in the cases where several Member States are suspected of failing to adhere to EU values all such Member States should not be given a chance to derail the application of Art. 7 TEU. Should the contrary be the case, all the procedural requirements of Art. 7 TEU, especially those requiring unanimity, would end up being deprived of their intended effet utile, given that the backsliding Member States would most likely obstruct the application of sanctions to each other's cases. Excluding several Member States from voting can thus be deemed as implicitly authorised by Art. 354 TFEU in the context of Art. 7, especially in the context of the Art. 7(2) TEU procedure. It will be up to the Court, when approached by one such Member State under Art. 269 TFEU, to clarify the exact extent of such an exclusion. Options potentially range from requiring the simultaneous consideration of the application of Art. 7(2) TEU to several backsliding Member States already subject to Art. 7(1) TEU procedure, to the default exclusion from the vote in the context of Art. 7 TEU of any state subjected to Art. 7(1) TEU in the context of any proceedings arising under Art. 7 TEU, without necessarily taking into simultaneous consideration the situation regarding the infringement of values in the several Member States.

The QMV required under Art. 354(2) TFEU is of the strictest nature, since the support of at least $72 \%$ of participating Council Members comprising $65 \%$ of the Union population is required as per direct reference to Art. 238(3)(b). As already mentioned, the Member State subjected to the procedure does not participate. The QMV could be even stricter in practice than its strictest emanation in the Treaties, since while Art. 354 TFEU speaks of excluding the Member State subjected to the procedure from the procedural thresholds concerning the numbers of Member States required to reach Art. 7 TEU decisions by the text of that provision, nothing in Art. 354 TFEU refers to the population threshold counts, which are part of the QMV. This leaves open two possible interpretations of QMV under Art. 354 TFEU: one including and one excluding the population of the Member State subjected to Art. 7 TEU procedure in the $65 \%$ of the Union population required. Given that no express reference is made to such an exclusion in Art. 354 TFEU, a strong argument can be made to include the population while excluding the Member State, while the contrary reading (exclusion of both the Member State and its population from the count) is more consistent with the raison d'être of the special procedure in question. The obvious lack of absolute clarity on this issue allows for the likelihood that the exact count of QMV thresholds will be the subject of a case in front of the CJEU under Art. 269 TFEU once an Art. 7 TEU procedure is activated. Art. 354 TFEU thus potentially requires the strictest QMV threshold available in the Treaties. 
Also, the EP's decision-making procedure deployed in Art. 7 TEU, as specified in Art. 354(4) TFEU, is exceptionally strict. A two-thirds majority of the votes cast representing the majority of component MEPs amounts to a much higher procedural threshold than a similar majority of the EP members present and voting. The votes cast in favour should thus come from at least the majority of the component members of the House, while also not falling below two-thirds of those present on the day of voting. How to count abstentions is not entirely clear based on the wording of Art. 354(4) TFEU, which posed a problem during the EP vote to activate Art. 7 TEU against Hungary in September 2018. Following the advice of the Directorate of Legislative Acts (the EP service responsible for the procedures), abstentions were not deemed to be 'votes cast', which affected the majority required. This reading is consistent with the interpretation of 'votes cast' in the context of Art. 231 TFEU and is supported by Rule 178(3) of the EP Rules of Procedure. Thus by analogy the two-thirds majority of 'votes cast' required in the context of Art. 354(4) TFEU is counted disregarding the abstentions. ${ }^{81}$ All in all the procedure thus contains two thresholds to be met by the EP, both of which are exceptionally high, especially in the context of the relatively low quorum rules in the EP.

\section{5 (Utopian) Scenarios for the Future: No Room for Art. 7}

Art. 7 TEU is unique in that it establishes the procedures for finding the threat of a breach of EU values by a Member State; the existence of such breach; as well as a possible sanctioning mechanism to bring the recalcitrant Member State(s) back into compliance, while not being confined by the general EU competence limitations. This commentary has briefly discussed all the sub-instruments and stages of deployment of the provisions in question and has demonstrated Art. 7's eminent usability, despite the claims by the institutions to the contrary, which are as baseless as they are persistent. The 'nuclear' myth, proclaiming Art. 7 TEU to be 'unusable' clearly lacks any connection with the observable legal reality. It is deployed by those in search of a valid pretext - however feeble - to exclude EU law from resolving a rule of law crisis of the European Union, which is a most problematic way of interpreting and employing EU law. In activating the 'naming and shaming' part of Art. 7 TEU, as we have seen with regard to Hungary and Poland, the EU does not and cannot solve any of the outstanding problems: this provision has not been designed to ensure regime change.

Crucially, Art. 7-and especially 7(2) TEU, which would be most appropriate in the current context - is atypical and difficult to use since it both contradicts the logic of the internal market and makes clear the Union's own vulnerabilities in the field of

\footnotetext{
${ }^{81}$ This did not prevent the Hungarian government from attempting to challenge the outcome of the vote in front of the CJEU, Case C-650/18 Hungary v. European Parliament (pending at the time of writing).
} 
the Rule of Law and democracy. It is a confrontational provision with a broad mandate for sanctions, which ensures economic losses throughout the internal market at the moment when its sanctions kick in, which is a direct spillover of the logic of economic integration into the sphere of protection of democracy and the rule of law. As a consequence, gathering the necessary political will to activate Art. 7 TEU is both immensely difficult and-ultimately-most likely a pointless exercise: Art. 7 TEU, no matter which procedural aspect of it we are talking about, does not bring with it any guarantee of regime change of the backsliding Member State. Consequently, it is not at all surprising that the only activations of Art. 7 TEU known to us happened only when the Member States in question de facto left the ambit of the rule of law world, as Sadurski, ${ }^{82}$ Scheppele, Sólyom ${ }^{83}$ and other scholars have clearly demonstrated. It seems that such activations, being ultimately entirely inconsequential-while offering one argument in a world of mutual recognition of disputes could potentially harm the EU more than the powers that be in Hungary and Poland.

Indeed, it is unfortunately beyond any doubt that the Commission's move to activate 7(1) TEU against Poland in 2018 will not result in any positive change on the ground in Poland. The Hungarian case is in no way different. Abundant time has passed to see that PiS and Fidesz do not inhabit a dialogue-friendly universe. The result of the Art. 7(1) procedure is thus most likely a new flow of insults from Warsaw, which does not help European values and is probably counter-productive in the eyes of ordinary Poles. The Commission and EP's actions are thus unlikely to bring about any positive change, and should be viewed as what they are-symbolic signals. Let us be frank here: the Treaties have failed to avert backsliding disasters in the Member States.

Three scenarios of possible action emerge in this context, all of them unrelated to Art. 7 TEU.

\subsection{Thinking Short-Term: Scenario No. 1: Cutting the Funds}

The preferred outcome of this realistic scenario would be a shake-up of the Polish and Hungarian political life to an extent likely to bring about speedy change- the populist government running out of cash will have to change its course. Unfortunately the amounts flowing into these backsliding states, however significant, are probably not suffient to bring about the expected result, so they should be scrutinised both with caution and skepticism.

\footnotetext{
${ }^{82}$ Sadurski (2018).

${ }^{83}$ Scheppele (2015), Sólyom (2015).
} 


\subsection{Thinking Mid-Term: Scenario No. 2: Overwhelming Ad Hoc Political Pressure}

Leaving aside its timidity with respect to the use of Art. 7, the Haider affair of 2000 has taught the Union a great lesson about how powerful political pressure outside the context of the Treaty framework can be. This aggressive tool, even if lying outside the realm of EU law sensu stricto, is sure to topple the PiS or Fidesz governments, triggering speedy change. The questions that arise in this regard are related to the sociological legitimacy of such actions and the powers to replace the autocrats. Blokker urges a lot of caution on this count, and he is most likely right.

\subsection{Thinking Long-Term: Scenario No. 3: A Multi-Speed Union}

This instrument would require strict political conditionality with respect to any move towards the core. A conditionality-based multi-speed Europe is unavoidable and the incorporation of conditionality techniques into policing each of the integration's concentric circles will be a necessary element of the edifice. As the speed and vectors of integration evolve, Poland and the likes of Poland could find themselves outside the scope of meaningful activity, i.e. behind the door of the integration kitchen. With the growing pressure on the Union's values from a number of countries, this seems like the most realistic way to preserve the EU as a union of values over the long term, while also being sufficiently open towards those states hijacked by Belarus-inspired plutocrats. Before blessing any moves between the concentric circles, a strict quarantine should be applied to the poisonous regimes outside the ambit of the values contained in Art. 2. However here too a voice of caution is in order: since the Commission has failed the conditionality exercise once, there is no guarantee it would succeed the second time round.

\section{A Realistic Scenario for the Future: No Room for Art. 7}

Gradual adaptation of the infringement proceedings to the needs of the current context is the final scenario proposed here for consideration. This scenario gets no number, since it is merely a description of the on-going developments. The Commission, together with the Court of Justice, is gradually pushing for the increasing the effectiveness of Arts. 258, 259, 260 and 279 TFEU as well as the Charter by using the principle of the independence of the judiciary and the EU-level function of the local judicial institutions in the backsliding Member States as the key trigger of 
jurisdiction. ${ }^{84}$ This approach is starting to yield results and is much less utopian that the other three outlined above. In being less utopian, it is also the most incremental and the least political, which endows it with additional legitimacy.

The crises have allowed the judiciaries of the EU to shine, bringing inter-court dialogue to a vital new level and upgrading its substance. ${ }^{85}$ At the core of this dialogue are also the fundamental principles of EU law, even those not confined in their entirety to the EU's scope of powers. ${ }^{86}$ In particular this includes the independence of the judiciary-interpreted by the CJEU as an EU-law principle and a vital element of the Rule of Law, ${ }^{87}$ as opposed to merely issues of validity and the interpretation of EU law per se, however broadly conceived. ${ }^{88}$ Such an interpretation-a spectacular innovation reshaping the constitutional system of the Union as we speak - has given voice to vertical concerns related to the independence of the judiciary, ${ }^{89}$ as well as horizontal rule of law concerns, leading to a significant refinement of the principle of mutual recognition..$^{90}$ This has allowed the Court to learn from its past mistakes in dealing with assaults on the rule of law. ${ }^{91}$ The presumption that the strict enforcement of the acquis is sufficient to guarantee adherence to the EU's values is clearly not valid any more. ${ }^{92}$ Together with the endowment of Art. 19(1) TEU with a new significance, the on-going crisis of the rule of law has helped open a new chapter of European constitutionalism. The very fact that the current concerns arose, rather than being strictly confined to the national legal orders, demonstrates the actual maturity of the level of supranational law and integration, or at least of its aspirations. ${ }^{93}$

A key element in the ongoing fight for the rule of law is, at the EU-level, the principle of the independence of the judiciary. This is derived from Art. 19(1) TEU

\footnotetext{
${ }^{84}$ Safjan and Düsterhaus (2014).

${ }^{85}$ Editorial comment (2019), p. 3; Dawson (2013), p. 371.

${ }^{86}$ For more on the shift of Art. 2 TEU principles from 'principles' to 'values' without undermining the essence of the former, see Pech (2010).

${ }^{87} \mathrm{CJEU}$, Case C-64/16 Associação sindical dos juízes portugueses, ECLI:EU:C:2018:117; Krajewski (2018), Pech and Platon (2018), Ciampi (2018).

${ }^{88}$ For a criticism of the classical inter-court dialogue before the most recent case-law, see e.g. Kochenov and van Wolferen (2018).

${ }^{89}$ This allowed the national courts under threat to deploy the preliminary ruling procedure in an innovative way in order to guarantee the preservation of their own independence: Biernat and Kawczyńska (2018); cf. Broberg (2017).

${ }^{90}$ E.g. CJEU, LM, Case C-216/18 PPU, supra note 25; Rizcallah (2018). Cf. Lenaerts (2017).

${ }^{91}$ Compare CJEU, Commission v. Hungary, Case C-286/12, supra note 21, with Commission v. Poland, Case C-619/18, supra note 22, Order ex parte of 19 October 2018 and Order of 17 December 2018.

${ }^{92}$ For more on this difference, see Kochenov (2017a).

${ }^{93}$ Even though numerous international organizations around the world facing similar crises are trying to resolve these with varyings degree of success: Closa (2017).
} 
and regarded as a vital part of the value of the rule of law. ${ }^{94}$ Judicial independence has thus emerged as a crucial nexus between EU law and the enforcement of Art. 2 TEU values outside of the scope of the acquis sensu stricto, ${ }^{95}$ which explains the relative silence over the Charter of Fundamental Rights (CFR) among those who are busy trying to deal hands-on with the ongoing rule of law concerns: ${ }^{96}$ Art. $51 \mathrm{CFR}$ still stands, despite all the literature on the need to move on from this competence block. ${ }^{97}$ After all, we are learning that 19 (1) TEU is good enough. ${ }^{98}$ A range of tools from pecuniary ${ }^{99}$ to interim measures having retroactive force ${ }^{100}$ can now be deployed to freeze at least some attempts on the part of the backsliding governments to undermine the independence of the judiciary even further. This new, more thoughtful approach could definitely have a significant impact of other areas of EU law too. It is marked however by one fundamental aspect: there is no place in it for Art. 7 TEU.

Acknowledgements I am grateful to Petra Bárd, Barabara Grabowska-Moroz, Marcus Klamert, Laurent Pech and Kim Lane Scheppele for their comments and reactions to earlier drafts. The research assistance of Chiraz Belhajali, Anna Gnap, Flips Schøyen and Jacquelyn Veraldi is gratefully acknowledged. This work has been conducted under the auspices of the EU's Horizon 2020 research and innovation programme as part of the RECONNECT project under Grant Agreement no. 770142. The chapter is a slightly rereferenced version of the contribution published by the Polish Yearbook of International Law in 2018.

\section{References}

Ahtisaari M, Frowein J, Oreja M (2001) Report on the Austrian Government's Commitment to the Common European Values, in particular concerning the rights of minorities, refugees and immigrants, and the evolution of the political nature of the FPÖ (The 'Wise Men Report'). Int Legal Mater 40:102-123

Amtenbrink F et al (2019) The internal market and the future of European integration. Cambridge University Press, Cambridge

Anselmi M (2018) Populism: an introduction (trans: Fano Morrisey L). Routledge, Oxon

Bánkuti M, Halmai G, Scheppele KL (2012) Hungary’s illiberal turn: disabling the constitution.

J Democr 23:138-146

\footnotetext{
${ }^{94} \mathrm{CJEU}$, Associação sindical dos juízes portugueses, Case C-64/16, supra note 87, paras. 36, 37 and 41 .

${ }^{95}$ Christophe Hillion predicted this development: Hillion (2016).

${ }^{96}$ Pech and Platon (2018), pp. 1833-1836.

${ }^{97}$ Jakab (2016, 2017). Cf. von Bogdandy et al. (2017).

${ }^{98}$ The connection with the Charter is however obvious: CJEU, Commission v. Poland, Case C-619/ 18, supra note 22, Order ex parte of 19 October 2018 and Order of 17 December 2018.

${ }^{99}$ Especially when the backsliding Member States attempt to openly defy the Court, CJEU, Case C441/17 Commission v. Poland, ECLI:EU:C:2018:255.

${ }^{100} \mathrm{CJEU}$, Commission v. Poland, Case C-619/18, supra note 22, Order ex parte of 19 October 2018 and Order of 17 December 2018.
} 
Bárd P, Śledzińska-Simon S (2019) Rule of Law Infringement Procedures: A Proposal to Extend the EU's Rule of Law Toolbox. CEPS Paper, 2019-09

Barroso JM (2012) State of the Union Address (Speech/12/596). European Parliament, Strasbourg, 12 September 2012. http://europa.eu/rapid/press-release_SPEECH-12-596_en.htm (last accessed 12 Sept 2019)

Belavusau U (2013) Case C-286/12 Commission v Hungary. Common Mark Law Rev 50:1145-1160

Bernatt M, Ziółkowski M (2019) Statutory anti-constitutionalism. Wash Int Law J 28:487-526

Besselink LFM (2017) The bite, the bark and the howl: Article 7 TEU and the rule of law initiatives. In: Jakab A, Kochenov D (eds) The enforcement of EU law and values. Oxford University Press, Oxford, pp 128-144

Bieber R, Maiani F (2014) Enhancing centralized enforcement of EU law: Pandora's toolbox? Common Mark Law Rev 51:1057-1092

Biernat S, Kawczyńska M (2018) Why the Polish Supreme Court's Reference on Judicial Independence to the ECJ is Admissible after All. Verfassungsblog, https://bit.ly/2IQxBvc (last accessed 12 Sept 2019)

Bignami F (ed) (2019) EU law in populist times. Cambridge University Press, Cambridge

Blagoev B (2011) Expulsion of a Member State from the EU after Lisbon: political threat or legal reality. Tilburg Law J 16:191-237

Blay-Grabarczyk K (2019) Les mécanismes de suivi à l'épreuve de la pratique: L'exemple de la Pologne. Revue Trimestrielle de Droit Européen 2019(2):321-335

Blokker P (2016) EU democratic oversight and domestic deviation from the rule of law: sociological reflections. In: Closa C, Kochenov D (eds) Reinforcing rule of law oversight in the European Union. Cambridge University Press, Cambridge, pp 249-269

Blokker P (2018) Populist Constitutionalism and Meaningful Popular Engagement. The Foundation for Law, Justice and Society Policy Brief

Blokker P (2019) Response to 'Public Law and Populism'. Germ Law J 20:284-290

Bodnar A (2018) Protection of human rights after the constitutional crisis in Poland. Jahrbuch des Öffentlichen Rechts der Gegenwart 66:639-663

Bribosia E, De Schutter O, Ronse T, Weyembergh A (2000) Le contrôle par l'Union européenne du respect de la démocratie et des droits de l'homme par ces États membres: à propos de l'Autriche. J Talent Dev Excell 67:61-64

Broberg M (2017) Preliminary references as a means of enforcement of EU law. In: Jakab A, Kochenov D (eds) The enforcement of EU law and values. Oxford University Press, Oxford, pp 99-111

Bugarič B (2015) A crisis of constitutional democracy in Central and Eastern Europe: 'lands in-between' democracy and autoritarianism. Int J Const Law 13:219-245

Bugarič B (2016) Protecting democracy inside the EU: on Article 7 TEU and the Hungarian turn to authoritarianism. In: Closa C, Kochenov D (eds) Reinforcing rule of law oversight in the European Union. Cambridge University Press, Cambridge, pp 82-102

Bugarič B (2019) Central Europe's descent into autocracy: a constitutional analysis of authoritarian populism. Int J Const Law 17:597-616

Carpano E (2005) État de droit et droits européens - l'évolution du modèle de l'État de droit dans le cadre de l'européanisation des systèmes juridiques. L'Harmattan, Paris

Carrera S, Faure Atger A (2010) L'affaire des Roms: A Challenge to the EU's Area of Freedom, Security and Justice. CEPS Liberty and Security in Europe Policy Paper, September 2010

Ciampi A (2018) Can the EU ensure respect for the rule of law by its Member States? The Case of Poland. Osservatorio sulle fonti 3:1-14

Closa C (2016) Reinforcing the rule of law: normative arguments, institutional proposals and procedural limitations. In: Closa C, Kochenov D (eds) Reinforcing rule of law oversight in the European Union. Cambridge University Press, Cambridge, pp 15-35 
Closa C (2017) Securing compliance with democracy in regional organizations. In: Jakab A, Kochenov D (eds) The enforcement of EU law and values. Oxford University Press, Oxford, pp 379-402

Closa C, Kochenov D (eds) (2016) Reinforcing rule of law oversight in the European Union. Cambridge University Press, Cambridge

Collot PA (2013) Difficulté contre-majoritaire et usage impérieux du pouvoir constituent dérivé au regard de la quatrième revision de la loi fondamentale de Hongrie. Revue française de droit constitutionel 14:789-812

Daly T (2019) Democratic decay: conceptualizing the emerging research field. Hague J Rule Law 11:9-36

Dawson M (2013) Constitutional dialogue between courts and legislatures in the European Union. Eur Public Law 19:369-396

Day (2018) Poland Becomes the First Country from Former Soviet Bloc to Be Ranked a 'Developed Market'. The Telegraph 24/09/2018. https://www.telegraph.co.uk/business/2018/09/24/ poland-becomes-first-country-former-soviet-bloc-ranked-developed/ (last accessed $12 \mathrm{Sept}$ 2019)

De Ridder E, Kochenov D (2011) Democratic conditionality in Eastern enlargement: ambitious window dressing. Eur Foreign Affairs Rev 16:589-605

Editorial Comment (2019) 2019 Shaping up as a challenging year for the Union, not least as a community of values. Common Mark Law Rev 56:3-22

Gormley LW (2017) Infringement proceedings. In: Jakab A, Kochenov D (eds) The enforcement of EU law and values. Oxford University Press, Oxford, pp 65-78

Hillion C (2004) The Copenhagen criteria and their progeny. In: Hillion C (ed) EU enlargement: a legal approach. Hart, Oxford, pp 1-22

Hillion C (2016) Overseeing the rule of law in the EU: legal mandate and means. In: Closa C, Kochenov D (eds) Reinforcing rule of law oversight in the European Union. Cambridge University Press, Cambridge, pp 59-81

Hirsch Ballin E (2016) Mutual trust: the virtue of reciprocity - strengthening the acceptance of the rule of law through peer review. In: Closa C, Kochenov D (eds) Reinforcing rule of law oversight in the European Union. Cambridge University Press, Cambridge, pp 133-146

Inglis K (2000) The Europe agreements compared in the light of their pre-accession reorientation. Common Mark Law Rev 37:1173-1210

Jakab A (2016) The EU Charter of fundamental rights as the most promising way of enforcing the rule of law against EU Member States. In: Closa C, Kochenov D (eds) Reinforcing rule of law oversight in the European Union. Cambridge University Press, Cambridge, pp 187-205

Jakab A (2017) The application of the EU Charter in National Courts in purely domestic cases. In: Jakab A, Kochenov D (eds) The enforcement of EU law and values. Oxford University Press, Oxford, pp 252-264

Jakab A, Kochenov D (eds) (2017a) The enforcement of EU law and values. Oxford University Press, Oxford

Jakab A, Kochenov D (2017b) Introductory remarks. In: Jakab A, Kochenov D (eds) The enforcement of EU law and values. Oxford University Press, Oxford, pp 1-8

Janse R (2019) Is the European Commission a credible guardian of the values? A revisionist account of the copenhagen political criteria during the big bang enlargement. Int J Const Law 17:43-65

Kelemen RD (2017) Europe's other democratic deficit: national authoritarianism in Europe's Democratic Union. Gov Oppos 52:211-238

Kelemen RD, Pech L, Scheppele KL (2018) Never Missing an Opportunity to Miss an Opportunity: The Council Legal Service Opinion on the Commission's EU Budget-Related Rule of Law Mechanism. Verfassungsblog, https://bit.ly/2PwVEy6 (last accessed 12 Sept 2019)

Klamert M, Kochenov D (2019) Article 2. In: Kellerbauer M, Klamert M, Tomkin J (eds) The treaties and the Charter of fundamental rights - a commentary. Oxford University Press, Oxford, pp 22-30 
Kochenov D (2005) EU enlargement law: history and recent developments - treaty-custom concubinage? Eur Integr Online Papers 9(6)

Kochenov D (2007) EU enlargement and the failure of conditionality. Kluwer Law International, New York

Kochenov D (2015) EU law without the rule of law: is the veneration of autonomy worth it? Yearb Eur Law 34:74-96

Kochenov D (2017a) The Acquis and its principles: the enforcement of the 'law' versus the enforcement of 'values' in the EU. In: Jakab A, Kochenov D (eds) The enforcement of EU law and values. Oxford University Press, Oxford, pp 9-27

Kochenov D (2017b) The EU and the Rule of Law - Naïveté or a Grand Design? In: Adams M, Meuwese A, Hirsch Ballin E (eds) Constitutionalism and the rule of law: bridging idealism and realism. Cambridge University Press, Cambridge

Kochenov D (2019a) Article 7 TEU. In: Kellerbauer M, Klamert M, Tomkin J (eds) The treaties and the Charter of fundamental rights - a commentary. Oxford University Press, Oxford, pp 88-102

Kochenov D (2019b) Article 354 TFEU. In: Kellerbauer M, Klamert M, Tomkin J (eds) The treaties and the Charter of fundamental rights - a commentary. Oxford University Press, Oxford, pp 2081-2091

Kochenov D (2019c) Elephants in the room: the European Commission's 2019 communication on the rule of law. Hague J Rule Law 11:423-438

Kochenov D, Bárd P (2019) The last soldier standing? Courts vs politicians and the rule of law crisis in the New Member States of the EU. Eur Yearb Const Law 1:243-287

Kochenov D, Basheska E (2016) ENP's values conditionality from enlargements to post-crimea. In: Poli S (ed) The EU and its values in the neighbourhood. Routledge, Oxon, pp 145-166

Kochenov D, Pech L (2015a) Renforcer le respect de l'État de droit dans l'UE: Regards critiques sur les noubeaux mécanismes proposes par la Commission et le Conseil. Fondation Robert Schuman Policy Paper no. 356/2015

Kochenov D, Pech L (2015b) Monitoring and enforcement of the rule of law in the European Union: rhetoric and reality. Eur Const Law Rev 11:512-540

Kochenov D, Pech L (2016) Better late than never? On the commission's rule of law framework and its first activation. J Common Mark Stud 24:1062-1074

Kochenov D, van Wolferen M (2018) The Dialogical Rule of Law and the Breakdown of Dialogue in the EU. EUI Working Paper, LAW 2018/01

Kochenov D, Pech L, Platon S (2015) Ni panacée, ni gadget: le 'nouveau cadre de l'Union européenne pour renforcer l'État de droit. Revue trimestrielle de droit européen 2015 (4):689-714

Kochenov D, Magen A, Pech L (eds) (2016) The great rule of law debate in the European Union. Symposium, J Common Mark Stud 54

Kochenov D, Pech L, Scheppele KL (2017) The European Commission's Activation of Article 7 TEU. Verfassungsblog. https://verfassungsblog.de/the-european-commissions-activation-ofarticle-7-better-late-than-never/ (last accessed 12 Sept 2019)

Koncewicz TT (2016) Of institutions, democracy, constitutional self-defence. Common Mark Law Rev 53:1753-1792

Koncewicz TT (2018) The capture of the polish constitutional tribunal and beyond: of institution(s), fidelities and the rule of law in flux. Rev Central East Eur Law 43:116-173

Krajewski M (2018) Associação sindical dos juízes portugueses: The Court of Justice and Athena's Dilemma. Eur Pap 3:395-407

Lachmayer K (2017) Questioning the basic values - Austria and Jörg Haider. In: Jakab A, Kochenov D (eds) The enforcement of EU law and values. Oxford University Press, Oxford, pp 436-455

Lenaerts K (2015) EU citizenship and the European Court of Justice's 'Stone-by-Stone' approach. Int Comp Jurisprud 1:1-10 
Lenaerts K (2017) La vie après l'avis: exploring the principle of mutual (yet not blind) trust. Common Mark Law Rev 54:805-840

Levrat N (2018) L'État de droit est-il une valuer européenne dont l'UE assure la promotion? In: Sidjanski D, Saint-Ouen F, Stephanou C (eds) Union des valuers? La mise en œuvre des valuers et des principes fondamentaux de l'Union Européenne. Global Studies Institute de l'Université de Genève, Geneva

Mastroianni R (2017a) Stato di diritto o ragion di stato? La difficcile rotta verso un controllo europeo del rispetto dei valori dell'unione negli stati memberi. In: Triggiani $\mathrm{E}$ et al (eds) Dialoghi con Ugo Villani. Cacucci, Bari, pp 605-617

Mastroianni R (2017b) Media Pluralism in Centro Europa 7 Srl, or when your competitor sets the rules. In: Nicola F, Davies B (eds) EU law stories: contextual and critical histories of European Jurisprudence. Cambridge University Press, Cambridge, pp 245-258

Merlingen M, Mudde C, Sedelmeier U (2001) The right and the righteous? European norms, domestic politics, and the sanctions against Austria. J Common Mark Stud 39:59-77

Mori P (2016) Strumenti giuridici e strumenti politici di controlle del rispetto dei diritti fondamentali da parte degli Stati membri dell'Unione europea. In: Tizzano A (ed) Verso 60 anni dai Trattati di Roma: stato e prospettive dell'Unione europea. Giappichelli, Torino, pp 199-209

Müller JW (2014) The EU as a Militant Democracy, or: are there limits to constitutional mutations within the Member States. Revista de Estudios Políticos 165:141-162

Müller JW (2015) Should the EU protect democracy and the rule of law inside Member States? Eur Law J 21:141-160

Oliver P, Stefanelli J (2016) Strengthening the rule of law in the EU: the council's inaction. J Common Mark Stud 24:1075-1084

Pech L (2010) 'A Union founded on the rule of law': meaning and reality of the rule of law as a constitutional principle of EU law. EU Const Law Rev 6:359-396

Pech L, Platon S (2017) Menace systémique envers l'État de droit en Pologne: entre action et proctastination. Fondation Robert Schuman Policy Paper no. 451, 13 Nov. 2017

Pech L, Platon S (2018) Judicial independence under threat: the Court of Justice to the rescue in the AJSP Case. Common Mark Law Rev 55:1827-1854

Pech L, Scheppele KL (2017) Illiberalism within: rule of law backsliding in the EU. Cambridge Yearb Eur Legal Stud 19:3-47, 8

Perju V (2018) On uses and misuses of human rights in European constitutionalism. In: Vöneky S, Neuman GL (eds) Human rights, democracy, and legitimacy in a world in disorder. Cambridge University Press, Cambridge

PolsatNews (2018) Artykuł 7 jest martwy; Komisja Europejska przegrała [Article 7 is dead; the European Commission has lost]. https://bit.ly/2IHo3Cy (last accessed on 13 Sept 2019)

Rideau J (2012) Les valeurs de l'Union européenne. Revue des affaires européennes 2012 (2):329-349

Rizcallah C (2018) Arrêt 'LM': un risqué de violation du droit fundamental à un tribunal indépendant s'oppose-t-il à l'exécution d'un mandate d'arrêt européen? Journal de droit européen 9:348-350

Sadurski W (2010) Adding bite to a bark: the story of Article 7, EU Enlargement, and Jörg Haider. Columbia J Eur Law 16:385-426

Sadurski W (2012) Constitutionalism and enlargement of Europe. Oxford University Press, Oxford

Sadurski W (2018) How Democracy Dies (in Poland): A Case Study of Anti-Constitutional Populist Backsliding. Sydney Law School Research Paper No. 18/01

Safjan M (2018) Domestic infringements of the rule of law as a European Union problem. Osteuropa Recht 64:552-560

Safjan M, Düsterhaus D (2014) A Union of effective judicial protection: addressing a multilevel challenge through the lens of Article 47 CFREU. Yearb Eur Law 33:3-40 
Scheppele KL (2015) Understanding Hungary's constitutional revolution. In: von Bogdandy A, Sonnevend $\mathrm{P}$ (eds) Constitutional crisis in the European constitutional area: theory, law and politics in Hungary and Romania. C. H. Beck, Hart, Nomos, pp 111-124

Scheppele KL (2016) Enforcing the basic principles of EU law through the systemic infringement procedure. In: Closa C, Kochenov D (eds) Reinforcing rule of law oversight in the European Union. Cambridge University Press, Cambridge, pp 105-132

Scheppele KL (2017) Constitutional coups in EU law. In: Adams M, Meuwese A, Hirsch Ballin E (eds) Constitutionalism and the rule of law: bridging idealism and realism. Cambridge University Press, Cambridge, pp 446-478

Scheppele KL (2018) Autocratic legalism. Univ Chicago Law Rev 85:545-583

Schmidt von Sydow H (2001) Liberté, Démocratie, Droits Fondamentaux et État de Droit: Analyse de l'Article 7 du Traité UE. Revue de droit de l'Union Européenne 2001(2):285-328

Sedelmeier U (2014) Anchoring democracy from above? The European Union and Democratic Backsliding in Hungary and Romania after Accession. J Common Mark Stud 52:105-121

Simon Z (2019) Hungary Becomes First 'Partly Free' EU Nation in Democracy Gauge. Bloomberg News 05/02/2019, https://www.bloomberg.com/news/articles/2019-02-05/hungary-becomesfirst-partly-free-eu-nation-in-democracy-gauge (last accessed on 13 Sept 2019)

Sólyom L (2015) The rise and decline of constitutional culture in Hungary. In: von Bogdandy A, Sonnevend P (eds) Constitutional crisis in the European constitutional area: theory, law and politics in Hungary and Romania. C. H. Beck, Hart, Nomos, pp 5-32

Szente Z (2017) Challenging the basic values - the problems with the rule of law in Hungary and the EU's Failure to Tackle Them. In: Jakab A, Kochenov D (eds) The enforcement of EU law and values. Oxford University Press, Oxford, pp 456-475

Timmermans F (2015) The European Union and the Rule of Law. Keynote Speech, Conference on the Rule of Law, Tilburg University, 3 August 2015. https://bit.ly/2Vpkg31 (last accessed on 13 Sept 2019)

Tóth GA (2017) Illiberal rule of law: changing features of Hungarian constitutionalism. In: Adams M, Meuwese A, Hirsch Ballin E (eds) Constitutionalism and the rule of law: bridging idealism and realism. Cambridge University Press, Cambridge, pp 386-416

Tsoukalis L (1981) The European Community and its mediterranean enlargement. Allen \& Unwin, Sydney

Vachudova MA, Spendzharova A (2012) The EU's Cooperation and Verification Mechanism: Fighting Corruption in Bulgaria and Romania after EU Accession. European Policy Analysis 2012/1

Varju M, Papp M (2016) The crisis, national particularism and EU law: what can we learn from the Hungarian Case? Common Mark Law Rev 53:1647-1674

von Bogdandy A (2019) Principles and challenges of a European Doctrine of systemic deficiencies. MPIL Research Paper 2019-14

von Bogdandy A, Ioannidis M (2014) Systemic deficiency in the rule of law: what it is, what has been done, what can be done. Common Mark Law Rev 51:59-96

von Bogdandy A, Sonnevend P (eds) (2015) Constitutional crisis in the European constitutional area: theory, law and politics in Hungary and Romania. C. H. Beck, Hart, Nomos

von Bogdandy A, Antpöhler C, Ioannidis M (2017) Protecting EU Values: reverse Solange and the rule of law framework. In: Jakab A, Kochenov D (eds) The enforcement of EU law and values. Oxford University Press, Oxford, pp 218-233

von Toggenburg GN (2001) La crisi austriaca: delicati equilibrismi sospesi tra molte dimensioni. Diritto pubblico comparato ed europeo 2:735-756

Waelbroek M, Oliver P (2017) La crise de l'État de droit dans 1'Union Européenne: Que faire?. Cahiers de droit européenne 2017/2:299-342

Weiler JHH (2012) The Schuman declaration as a manifesto of political messianism. In: Dickson J, Eleftheriadis P (eds) Philosophical foundations of European Union law. Oxford University Press, Oxford 
Weiler JHH (2016) Living in a Glass House: Europe, democracy and the rule of law. In: Closa C, Kochenov D (eds) Reinforcing rule of law oversight in the European Union. Cambridge University Press, Cambridge, pp 313-326

Wennerås P (2017) Making effective use of Article 260. In: Jakab A, Kochenov D (eds) The enforcement of EU law and values. Oxford University Press, Oxford, pp 79-98

Williams A (2006) The indifferent gesture: Article 7 TEU, the fundamental rights agency and the UK's Invasion of Iraq. Eur Law Rev 31:3-27

Williams A (2009) The ethos of Europe. Cambridge University Press, Cambridge

Wilms G (2017) Protecting fundamental values in the European Union through the rule of law.

European University Institute, Florence

Dimitry Kochenov is a Professor of EU Constitutional Law at the University of Groningen.

Open Access This chapter is licensed under the terms of the Creative Commons Attribution 4.0 International License (http://creativecommons.org/licenses/by/4.0/), which permits use, sharing, adaptation, distribution and reproduction in any medium or format, as long as you give appropriate credit to the original author(s) and the source, provide a link to the Creative Commons license and indicate if changes were made.

The images or other third party material in this chapter are included in the chapter's Creative Commons license, unless indicated otherwise in a credit line to the material. If material is not included in the chapter's Creative Commons license and your intended use is not permitted by statutory regulation or exceeds the permitted use, you will need to obtain permission directly from the copyright holder. 